\title{
Some aspects of purinergic signaling in the ventricular system of porcine brain
}

\author{
Joanna Czarnecka ${ }^{1}, K^{2}$ atarzyna Roszek ${ }^{1}$, Artur Jabłoński ${ }^{2}$, Dariusz Jan Smoliński ${ }^{3}$ and Michał Komoszyński ${ }^{*}$
}

\begin{abstract}
Background: Numerous signaling pathways function in the brain ventricular system, including the most important - GABAergic, glutaminergic and dopaminergic signaling. Purinergic signalization system - comprising nucleotide receptors, nucleotidases, ATP and adenosine and their degradation products - are also present in the brain. However, the precise role of nucleotide signalling pathway in the ventricular system has been not elucidated so far. The aim of our research was the identification of all three elements of purinergic signaling pathway in the porcine brain ventricular system.

Results: Besides nucleotide receptors on the ependymocytes surface, we studied purines and pyrimidines in the CSF, including mechanisms of nucleotide signaling in the swine model (Sus scrofa domestica). The results indicate presence of $G$ proteins coupled P2Y receptors on ependymocytes and also P2X receptors engaged in fast signal transmission. Additionally we found in CSF nucleotides and adenosine in the concentration sufficient to $P$ receptors activation. These extracellular nucleotides are metabolised by adenylate kinase and nucleotidases from at least two families: NTPDases and NPPases. A low activity of these nucleotide metabolising enzymes maintains nucleotides concentration in ventricular system in micromolar range. ATP is degraded into adenosine and inosine.

Conclusions: Our results confirm the thesis about cross-talking between brain and ventricular system functioning in physiological as well as pathological conditions. The close interaction of brain and ventricular system may elicit changes in qualitative and quantitative composition of purines and pyrimidines in CSF. These changes can be dependent on the physiological state of brain, including pathological processes in CNS.
\end{abstract}

Keywords: extracellular nucleotides, ecto-nucleotidases, exo-nucleotidases, nucleotide receptor, brain ventricular system

\section{Background}

Ventricular system is composed of brain structures lined with ependyma and is filled with cerebrospinal fluid (CSF). The composition and physico-chemical properties of CSF depend on the physiological condition of brain. In turn, the composition of CSF influences the function of brain cells. It is well known that cerebrospinal fluid transports signaling molecules and trophic factors generating complex physiological responses due to the activation of their appropriate receptors present on the cells contacting the CSF [1-4]

There are numerous signalization pathways functioning in the brain ventricular system. The most important

\footnotetext{
* Correspondence: michkom@chem.umk.pl

'Biochemistry Department, Institute of General and Molecular Biology,

Nicolaus Copernicus University, 7 Gagarina St, 87-100 Torun, Poland

Full list of author information is available at the end of the article
}

are GABAergic, glutaminergic and dopaminergic signaling [5-11]. Elements of purinergic signalization system nucleotide receptors, nucleotidases, ATP and adenosine and their degradation products - are also present in that brain structure [1-4,12-16].

Purines such as adenine and guanine beside committed in neurotransmition and neuromodulation also function as trophic factors [17-19]. Ectopurines are involved in the activation of differentiation and neuritogenesis of precursor cells and neurons. They stimulate synthesis and release of trophic factors in neuronal and glial cells and enhance the effect of growth factors $[17,18]$. Purines also participate in immunological response due to astrocytes and microglia activation, initiation of inflammatory reactions, apoptosis and necrosis, as well as glial cell proliferation $[17,18,20,21]$. Extracellular purines bring about signaling or transfer of

\section{() Biomed Central}


the information by activating two classes of the receptors: P1-adenosine receptors and P2-nucleotide receptors $[19,22]$. The activation of $\mathrm{P} 1$ and $\mathrm{P} 2$ receptors affects metabolic processes, adhesion, motility and proliferation capability of cells [23,24]. The P1 and P2 receptors are colocalized in the most types of cells, where they act antagonistically and regulate the physiological processes [19,22,25-27].

The purines concentration outside the cell depends on the balance between their release from the cells, uptake and extracellular metabolism $[19,25]$. The purine nucleotides outside the cell are metabolised by ectonucleotidases [25,27]. Activity of these enzymes was detected in all examined living organisms: plants, bacteria, animals and human [25].

All known ecto-enzymes controlling the nucleotides concentration belong to several families, differing in origin and mechanism of action. There are four families of nucleotidases: NTPDases (nucleoside triphosphate diphosphohydrolases), NPPases (pyrophosphohydrolases/phosphodiesterases), phosphatases and ecto-5'nucleotidase. The next group of ecto-enzymes involved in regulation of nucleotides concentration outside the cell are nucleotide kinases - the enzymes that transfer the phosphate moiety between nucleotides. Numerous investigations show that ecto-enzymes metabolizing nucleotides outside the cell are involved in termination of nucleotide signaling pathway due to releasing ligands from their receptors [25,28,29]. Additionally, nucleotidases and kinases may produce other secondary messengers like ATP, ADP and adenosine.

According to the previous studies on rodent brain ventricular system, nucleotide receptors $\mathrm{P}_{2} \mathrm{X}_{7}$ are localized on the surface of cells lining the cerebral ventricles and cells of choroid plexus $[16,30]$. P2 $\mathrm{X}_{2}$ mRNA has been found in neurons contacting CSF in rat spinal cord [15]. However, the precise role of nucleotide signaling pathway in the ventricular system has not been elucidated so far. Surprisingly, there are no data demonstrating the extracellular purines metabolism within the ventricular system of mammals other than rodents. There is little information concerning the soluble nucleotidases in CSF [16,31], and virtually nothing is known about ependymal membrane-bound nucleotidases.

The aim of our research was to elucidate if all three elements of purinergic signaling pathway, including nucleotide receptors on the ependymocytes surface, purines and pyrimidines in the CSF and mechanisms of nucleotide signal termination, are present in the porcine brain ventricular system.

\section{Materials and methods}

\subsection{Reagents}

We used the following reagents: ethanolamine, $n$-heptane, $\mathrm{KCl}, \mathrm{HClO}_{4}$ and EDTA (POCh Gliwice, Poland, p.a. grade), $\mathrm{KH}_{2} \mathrm{PO}_{4}, \mathrm{~K}_{2} \mathrm{HPO}_{4}$, tetrabutylammonium hydrogen sulphate (TBA) and isocratic methanol (Baker Phillipsburg, USA, HPLC grade). The following nucleotides and nucleosides: Adenosine-5'-triphosphate, adenosine-5'diphosphate, adenosine-5'-monophosphate, adenosine, guanosine-5'-triphosphate, guanosine-5'-diphosphate, uridine-5'-triphosphate, uridine-5'-diphosphate (98-99\% purity, Sigma-Aldrich, Europe) were used as substrates for enzyme activity determination and as HPLC standards.

For molecular biology analyses: First Strand cDNA Synthesis Kit (Fermentas, Lithuania), primary rabbit antibodies - anti-P2X $\mathrm{X}_{7}$, anti-P2X $\mathrm{X}_{2}$ and anti-P2Y $\mathrm{Y}_{2}$ (SigmaAldrich, Europe), Alexa Fluor 488 secondary anti-rabbit antibody (Molecular Probes, Leiden, Holland) were used.

Primers were synthesized in DNA Sequencing and Oligonucleotide Synthesis Lab (Institute of Biochemistry and Biophysics, Polish Academy of Sciences, Warsaw, Poland).

\subsection{Materials}

Cerebrospinal fluids (CSFs) of healthy swines were collected in Department of Swine Diseases, National Veterinary Research Institute (Puławy, Poland) following ethical procedures laid by ethical committee of the university. CSFs were centrifuged $10 \mathrm{~min}$ at $20000 \times g$ to discard the morphotic elements. The supernatant obtained was immediately used to determine enzymatic activity. Portions of the CSFs were cooled to $4^{\circ} \mathrm{C}$, frozen and then stored at $-80^{\circ} \mathrm{C}$. After thawing the CSFs were centrifuged and used to determine nucleotide concentrations.

Porcine brains collected immediately after slaughter, were placed in cold $\left(4^{\circ} \mathrm{C}\right)$ isotonic buffer A $(35 \mathrm{mM}$ Tris- $\mathrm{HCl} \mathrm{pH} \mathrm{7.4,} 250 \mathrm{mM}$ sucrose, $10 \mathrm{mM}$ glucose) with $4 \mathrm{mM} \mathrm{MgCl}_{2}$ and $2 \mathrm{mM} \mathrm{CaCl}$. The tissue from lateral ventricle was cut into slices $(1 \mathrm{~cm}$ diameter, $0.785 \mathrm{~cm}^{2}$ ) and used to determine membrane bound activity of enzymes from ependymal cells. The fragments of lateral ventricle wall were cut with the use of sharp steel tubing and immobilized in alginate with the ependymal layer directed upside. These fragments of ventrical wall were used to immunohistochemical localisation of nucleotide receptors as well as for expression analysis of nucleotidases.

\subsection{Qualitative and quantitative analysis of purines and pyrimidines}

The already established method of solid phase extraction (SPE) of purines and pyrimidines [32] and high-performance liquid chromatography (HPLC) was and used in the experiments.

\subsection{Enzymatic activity determination}

Nucleotidases assay in CSFs was carried out in incubation mixture composed of: isotonic buffer A with $3 \mathrm{mM}$ 
$\mathrm{Mg}^{2+}$ or $2 \mathrm{mM} \mathrm{Ca}^{2+}, 2.5 \mathrm{mM}$ levamisol (alkaline phosphatase inhibitor) [33], $0.1 \mathrm{mM}$ dipiridamol (adenosine deaminase inhibitor) [34], and 1 or $2 \mathrm{mM}$ nucleotide (ATP, ADP, AMP) as substrate. To distinguish nucleotidases $0.1 \mathrm{mM}$ suramine (NTPDase inhibitor [35]) or 10 $\mu \mathrm{M}$ Ap5A (NPPase and adenylate kinase inhibitor $[36,37])$ were added to incubation mixture.

Adenylate kinase assay in CSFs was carried out in isotonic buffer A containing $3 \mathrm{mM} \mathrm{Mg}^{2+}, 2.5 \mathrm{mM}$ levamisol, $0.1 \mathrm{mM}$ dipiridamol, $0.1 \mathrm{mM}$ suramine (buffer A) and $2 \mathrm{mM}$ ADP as substrate.

Enzymatic reactions were initiated with $20 \mu \mathrm{l} \mathrm{CSF}$ added to $20 \mu \mathrm{l}$ of pre-warmed incubation mixture. The samples were incubated for $15-120 \mathrm{~min}$ at $37^{\circ} \mathrm{C}$ and reaction was terminated with $20 \mu \mathrm{l}$ of $1 \mathrm{M}$ cold $\mathrm{HClO}_{4}$. All tested samples were neutralized with $1 \mathrm{M} \mathrm{KOH}$, delipidated by shaking with $n$-heptane $(1: 5, \mathrm{v} / \mathrm{v})$, centrifuged and analysed for qualitative and quantitative analysis of purines concentration.

Determination of ependymal ecto-enzymes activity was carried out in situ on the tissue surface. The tissue slices were incubated for 10-30 min with appropriate incubation mixtures at $37^{\circ} \mathrm{C}$. The reaction was terminated by adding $50 \mu \mathrm{l}$ of incubation mixture to $50 \mu \mathrm{l}$ of $1 \mathrm{M}$ cold $\mathrm{HClO}_{4}$. All tested samples were prepared for the analysis of purines concentration as described above.

The effect of divalent ions influence on the activity of porcine brain ventricular system enzymes was determined in the presence of $2 \mathrm{mM} \mathrm{Ca}^{2+}$ and $3 \mathrm{mM} \mathrm{Mg}^{2+}$.

The $\mathrm{pH}$ optimum of enzymes metabolizing nucleotides in ventricular system was carried out in $\mathrm{pH}$ range between 6.0 to 9.0 , in isotonic conditions and in the presence of appropriate divalent ions and inhibitors blocking the enzymatic activities of other enzymes.

\subsection{Protein assay}

Protein concentration was determined by the method of Bradford [38] using bovine serum albumin as a standard.

\subsection{Western blotting}

After completing SDS-PAGE and electrophoretic transfer onto the nitrocellulose, the membrane was blocked in 3\% BSA in TBS for 1 hour. The membrane was then incubated for 2 hours at room temperature with the rabbit polyclonal primary antibody (antiNTPDase1 (CD39) antibodies, anti-apyrase antibodies, anti-NTPDase 5 antibodies or anti-NPPase3 antibodies were used respectively, depending on the experiment, all the antibodies were purchased from Santa Cruz Biotechnology, Inc.). After washing with TBS, the membrane was incubated with the secondary antibody (anti-rabbit IgG Alkaline Phosphatase Conjugate) for 2 hours at room temperature. After removing the antibody, the alkaline phosphatase reagents (BCIP/ NBT) were added.

\subsection{NTPDases and NPPases expression analysis in ependymal cells}

Total RNA was isolated from ependymocytes obtained by trypsynization of the ependymal surface with $0.25 \%$ trypsin and from fragments of brain tissue (positive control) frozen in liquid nitrogen. The reverse transcription was carried out with the use of First Strand cDNA Synthesis Kit. The primer sequences were designed as shown in Table 1.

The amplified cDNA fragments were electrophoresed in $1 \%$ agarose gel, stained with ethidium bromide and photographed under an ultraviolet light transilluminator.

\subsection{Immunolocalization of nucleotide receptors on the surface of porcine brain ventricle lining}

Fragments of intact ependymal surface obtained as indicated in section 2.2, were incubated with primary antibodies: anti-P2X $\mathrm{X}_{7}$, anti-P2X $\mathrm{X}_{2}$ and anti- $\mathrm{P} 2 \mathrm{Y}_{2}$ ( 1 hour at $7^{\circ}$ $\mathrm{C})$ and subsequently with secondary antibodies conjugated with Alexa Fluor $488\left(1\right.$ hour at $\left.7^{\circ} \mathrm{C}\right)$. Preparations were analysed using confocal laser scanning microscope (Nikon Eclipse TE 300 CLSM) with Plan Apochromat $60 \times$ objective. The Alexa Fluor 488 excitation with helium-neon laser $(\lambda=543 \mathrm{~nm})$ resulted in red fluorescence of the fluorophore. The images were photographed with EZ 2000 Viewer for Confocal Microscope PCM 2000.

\section{Results}

Nucleotides and nucleosides of porcine brain ventricular system

The cerebrospinal fluids (CSF) of seven healthy swines were used for qualitative and quantitative analyses of purines and pyrimidines. The selected animals were matched in respect to equal breed, age and farming conditions.

In porcine CSF we identified 8 purines and pirymidynes: ATP, ADP, AMP, Ado, GTP, GDP, UTP and UDP (Table 2). The values of standard deviation and median values similar to arithmetical mean are shown. We found that guanine nucleotides concentrations in analyzed CSF are significantly higher than adenine nucleotides concentrations. The $[\mathrm{GTP}] /[\mathrm{ATP}]$ ratio is about $8: 1$ whereas the [GDP]/[ADP] ratio is 6:1. UTP was present only in 4 and UDP in 6 samples of analyzed CSF.

\section{Immunochemical localization of nucleotide receptors on the surface of porcine brain ependyma}

We confirmed the presence of nucleotide receptors $\mathrm{P}_{2} \mathrm{X}_{7}, \mathrm{P}_{2} \mathrm{X}_{2}$ and $\mathrm{P} 2 \mathrm{Y}_{2}$ in the ventricular system of porcine brain. These experiments were conducted on the 
Table 1 Primer sequences

\begin{tabular}{ccc}
\hline ENZYME & FORWARD & REVERSE \\
\hline NTPDase1 & 5'-CTACCCCTTTGACTTCCAGG-3' & 5'-GCACACTGGGAGTAAGGGC-3' $^{\prime}$ \\
\hline NTPDase2 & 5'-GGAGGCGAAGAGCAGG-3' & 5'-TGGAGGCAGCCGCATGAAT-3' \\
\hline NTPDase3 & 5'-ACCCCAGGCTGACTCTAAGC-3' \\
\hline NTPDase5 & 5'-GTGAAAGGTGGCTCCCAA-3' & 5'-CTTAGAGGTAGCCAAAGACTC-3' \\
\hline NTPDase6 & 5'-ATGGGACCTTGCGGATGACGA-3' & 5'-CCAAGCAACACATTCCATA-3' \\
\hline NPPase3 & 5'-GTCAGAGCCATGAAATCCACT-3' & 5'TCAGTACCATTTGAAGAAAGGATTTAGCTGTTCT-3' \\
\hline
\end{tabular}

unfixed samples of ependymal layer that significantly lowered the auto-fluorescence of brain tissue. P2X receptors are the most abundantly expressed nucleotide receptors on the ependymal cells (Figure $1 b$ ) whereas $\mathrm{P}_{2} \mathrm{X}_{2}$ receptors are less frequent and positive signals of anti-P2X $\mathrm{X}_{2}$ antibodies are concentrated in specific regions of ependyma (Figure 1c). The widely expressed $\mathrm{P}_{2} \mathrm{Y}_{2}$ receptor in brain tissue is present on ependymal cells in streaks forming clusters (Figure 1d). The streaks of ependymal cells had been previously observed under electron microscope [39].

The enzymes acting in nucleotides metabolism of porcine brain ventricular system

Nucleotides in CSF were hydrolysed by enzymes localized on the ependymal surface (ecto-nucleotidases) as well as by soluble enzymes present in CSF (exonucleotidases). These enzymes efficiently metabolised purine triand diphosphonucleotides (ATP > ADP > GTP > GDP). We also found the activity of 5'nucleotidase (Table 3) despite the fact that purine monophosphonucleotides and pyrimidynes were hydrolysed less efficiently.

The kinetical analyses (inhibitors, ions and $\mathrm{pH}$ influence on the enzymes activity), Western Blotting and gene expression analyses helped to identify the nucleotidases present in brain ventricular system.

Ecto-enzymes associated with the ependymal cells surface and exo-enzymes present in CSF differed in their optimum $\mathrm{pH}$ or sensitivity to divalent ions. The different reaction products suggest that analysed enzymes belong to two distinct classes of hydrolases and kinases. The results are summarized in Table 4 .

At pH 6.5 enzymes of CSF and ependymal ectoenzymes use ADP to synthesize ATP. This reaction was activated by $\mathrm{Mg}^{2+}$ ions, whereas Ap5A (kinase inhibitor) efficiently inhibited ATP synthesis, suggesting that nucleotide kinases are present in porcine CSF and on the surface of porcine brain ventricle lining.

\section{Kinetical analyses of ependymal ecto-hydrolases}

The values of optimal $\mathrm{pH}$ conditions for ATP to ADP hydrolysis at $\mathrm{pH} 7.5$ were distinct from the optimal $\mathrm{pH}$ value 8.5 required for ATP to AMP hydrolysis. The ATP hydrolysis by ependymal ecto-enzymes at $\mathrm{pH} 7.5$ was efficiently inhibited by suramine (NTPDases inhibitor) whereas Ap5A has no inhibitory effect. On the other hand, ATP to AMP hydrolysis at pH 8.5 was strongly inhibited by Ap5A (NPPases inhibitor).

ADP to AMP hydrolysis was most efficient at $\mathrm{pH} 7.5$ and the hydrolytic activity decreased in the presence of suramine. These results indicate that ecto-NTPDase2, ecto-NPPase and enzyme ecto-NTPDase5, 6-like are the most active enzymes on the surface of ependymal cells.

\section{Kinetical analyses of exohydrolases in cerebrospinal fluid}

Further we found exo-enzymes in CSF that catalysed ATP to ADP hydrolysis at $\mathrm{pH}$ 7.0. ATP hydrolysis at this $\mathrm{pH}$ was efficiently inhibited by suramine and Ap5A. ATP to AMP was hydrolysed less efficiently - this process constituted only $20 \%$ of ATP to ADP hydrolysis.

The inhibitory effect of Ap5A on ADP to AMP hydrolytic activity was stronger in the presence of magnesium (64\%) than calcium ions (40\%). However, the inhibitory effect of suramine was stronger in the presence of calcium (49\%) than magnesium ions (17\%). These results indicate presence of soluble exoenzyme NTPDase2 activity in porcine CSF. The differences in the susceptibility of ADP to AMP hydrolysis to inhibitors, observed in the presence of $\mathrm{Mg}^{2+} \mathrm{i} \mathrm{Ca}^{2+}$, indicate that the enzymes with NPPase-like activity (strong inhibition with Ap5A in presence of $\left.\mathrm{Mg}^{2+}[36,37]\right)$ and NTPDase 5 or NTPDase6 activity (strong inhibition with suramine in presence of $\left.\mathrm{Ca}^{2+}[35]\right)$ are present in CSF of swine.

Table 2 Purines and pyrimidines concentration in porcine CSF

\begin{tabular}{ccccccccc}
\hline & ATP & ADP & AMP & Ado & GTP & GDP & UTP & UDP \\
\hline Purines concentration $[\mu \mathrm{M}]$ & $1.04 \pm 0.20^{*}$ & $3.71 \pm 2.01$ & $2.07 \pm 0.88$ & $2.20 \pm 0.38$ & $8.01 \pm 3.79$ & $20.35 \pm 10.21$ & $2.43 \pm 1.3$ & $0.32 \pm 0.21$ \\
\hline Median & 0.98 & 4.25 & 1.92 & 2.23 & 7.67 & 21.00 & 0.99 & 0.18 \\
\hline
\end{tabular}

*the results are expressed as mean \pm standard deviation 

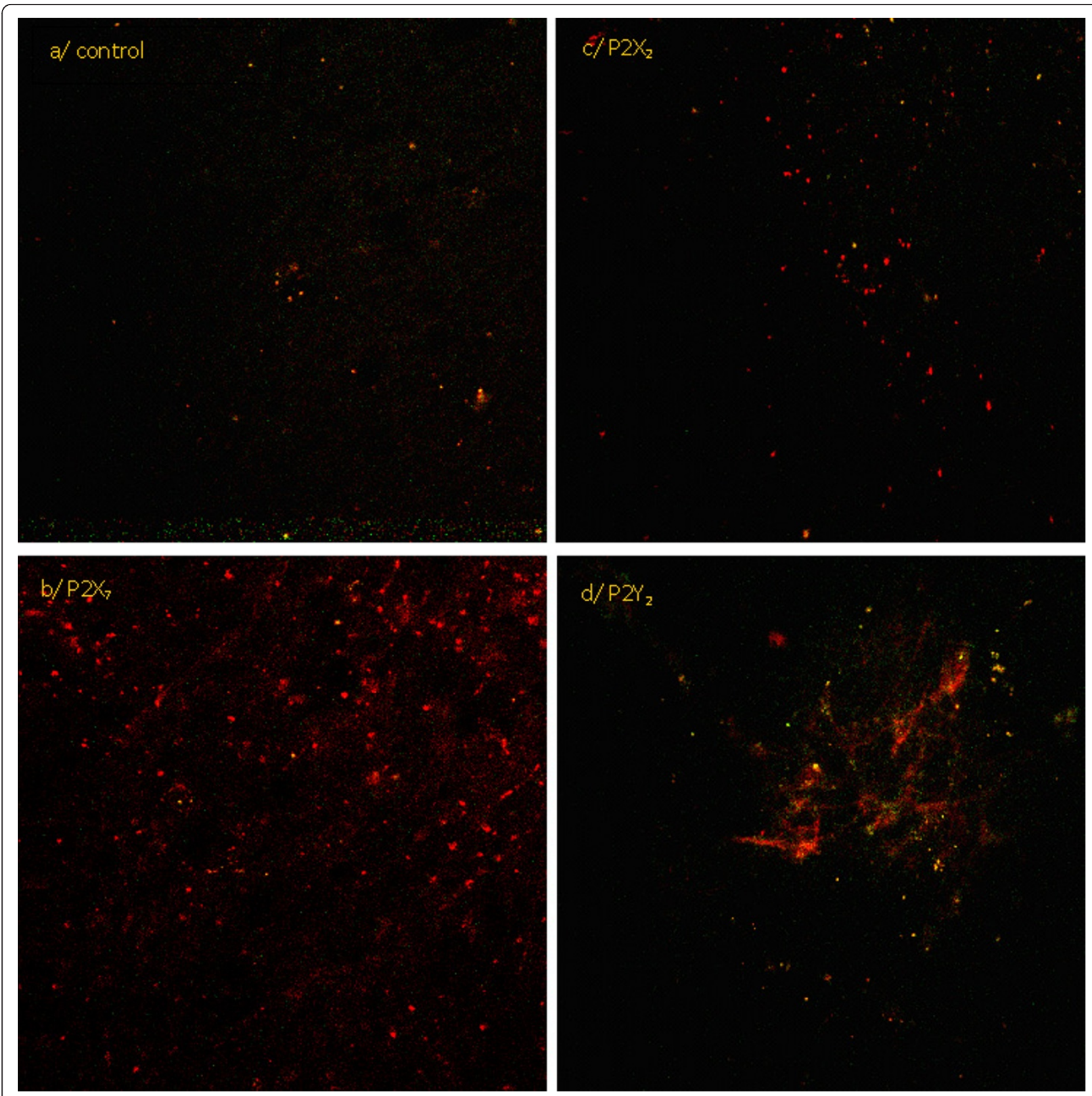

Figure 1 Immunochemical localization of nucleotide receptors on the ependymal cells surface. Signals from single anti-receptor antibodies (red), co-localized signals from antibodies (yellow), the auto-fluorescence of brain tissue (green).

\section{Molecular identification of brain ventricular system nucleotidases}

The enzymatic proteins present in porcine CSF were detected and identified. The results of SDS-PAGE electrophoresis and Western Blot analyses are shown in Figure 2.

The presence of enzymes from NTPDase and NPPase families in porcine CSF was confirmed by their molecular mass (Figure 2A) as well as Western Blotting analyses. However, the precise identification of the enzymes was impossible. The molecular weight of proteins interacting with applied anti-NTPDases primary antibodies was about $64 \mathrm{kDa}, 62 \mathrm{kDa}$ and $58 \mathrm{kDa}$ respectively (Figure $2 \mathrm{~B}, \mathrm{D})$. It is consistent with the molecular weight of soluble NTPDases of blood vessels [25,40] and apyrase of $A$. thaliana (Figure 2C). The proteins interacting with anti-NPPases antibodies reflected molecular weight of about $52 \mathrm{kDa}$ and $58 \mathrm{kDa}$ (Figure 2D, E). These data are in good agreement with molecular weight of soluble NPPases found in literature [41-48]. 
Table 3 Substrate specificity of ependymal cells ectonucleotidases and exonucleotidases in CSF

\begin{tabular}{|c|c|c|}
\hline \multirow[t]{2}{*}{ Substrate } & \multicolumn{2}{|c|}{ Activity (\%) } \\
\hline & Ecto-nucleotidases* & Exo-nucleotidases** \\
\hline ATP & 100 & 100 \\
\hline ADP & $95.1 \pm 8.1$ & $91.1 \pm 6.2$ \\
\hline GTP & $60.0 \pm 6.8$ & $79.6 \pm 7.6$ \\
\hline GDP & $42.3 \pm 9.9$ & $75.4 \pm 7.9$ \\
\hline AMP & $12.2 \pm 3.8$ & $5.8 \pm 3.2$ \\
\hline CTP & $5.1 \pm 2.4$ & $9.0 \pm 2.9$ \\
\hline GMP & $4.8 \pm 1.8$ & $7.2 \pm 3.2$ \\
\hline TTP & $3.7 \pm 1.4$ & $5.7 \pm 3.5$ \\
\hline CDP & $3.3 \pm 2.1$ & $4.1 \pm 2.1$ \\
\hline TDP & $0.8 \pm 0.3$ & $0.5 \pm 0.6$ \\
\hline
\end{tabular}

The above experiments on gene expression indicate, that genes coding the soluble NPPase3 (Figure 3.1E), NTPDase5 (Figure 3.3E) and NTPDase6 (Figure 3.5E) as well as NTPDase2 (Figure 3.2E) are expressed in ependymal cells.

PCR products obtained with the use of primers for NTPDase 5 from porcine brain cells and ependymal cells were different in respect of their size (Figure 3.3), suggesting distinct splicing of NTPDase5 in ependymal cells than its splicing in the brain.
Our results show that there is no NTPDase1 expression in ependymal cells of porcine brain (Figure 3.5E), whereas it is expressed in brain (positive control, Figure $3.5 \mathrm{M})$. The absence of NTPDase1 expression in ependymal cells may constitute the negative control used for the identification of these cells.

The presence of NTPDase3 in ventricular system of porcine brain cannot be confirmed by PCR reactions. However, in the literature there are data concerning the NTPDase3 expression in mammalian and human brain $[49,50]$.

\section{Discussion}

The results presented in this paper for the first time demonstrate the presence of all three elements of purinergic signaling in the swine (Sus scrofa domestica) brain ventricular system. Several previous studies showed the correlation between concentration of nucleotides, nucleosides and purine/pyrimidine bases in extracellular spaces of brain tissue and cerebrospinal fluid [1-4,12-14]. However, previous experiments on ventricular system metabolism were conducted in rodents [5,15,39,51-56]. Rodents brain tissue retained quite well functioning repair processes because of high differentiating potential of neuronal stem cells present in the subventricular zone $[57,58]$. In the contrary to other mammalian brains, the brain of rodents responds differently to the non-physiological conditions, like ischemia or hypoxia, that damage cells of the central nervous system $[54,55,59]$.

Table 4 The activity of nucleotidases of brain ventricular system under optimal pH conditions

\begin{tabular}{|c|c|c|c|c|c|}
\hline \multicolumn{2}{|c|}{ Incubation mixture } & \multicolumn{4}{|c|}{ Ependymal ecto-enzymes activity $\left(\mathrm{nmol} \times \mathrm{min}^{-1} \times\left(\mathrm{cm}^{2}\right)^{-1}\right)^{*}$} \\
\hline \multirow[t]{2}{*}{ Ion } & Inhibitor & $\mathrm{ATP}=>\mathrm{ADP}$ & $A T P=>A M P$ & $A D P=>A M P$ & $A D P=>A T P$ \\
\hline & & $\mathrm{pH} 7.5$ & $\mathrm{pH} 8.5$ & $\mathrm{pH} 7.5$ & pH 6.5 \\
\hline \multirow[t]{3}{*}{$\mathrm{Ca}^{2+}$} & Control (without inhibitor) & $19.2 \pm 1.1$ & $20.1 \pm 3.6$ & $17.8 \pm 3.5$ & $11.3 \pm 1.2$ \\
\hline & Suramine & $6.9 \pm 1.2$ & $17.2 \pm 2.8$ & $7.6 \pm 1.3$ & $11.2 \pm 1.7$ \\
\hline & Ap5A & $16.5 \pm 2.3$ & $5.2 \pm 0.9$ & $17.7 \pm 2.1$ & $4.2 \pm 1.0$ \\
\hline \multirow[t]{3}{*}{$\mathrm{Mg}^{2+}$} & Control (without inhibitor) & $19.4 \pm 1.9$ & $20.4 \pm 2.4$ & $16.7 \pm 2.0$ & $18.5 \pm 1.9$ \\
\hline & Suramine & $7.1 \pm 2.0$ & $19.4 \pm 2.5$ & $6.9 \pm 1.5$ & $18.2 \pm 1.9$ \\
\hline & Ap5A & $21.0 \pm 3.5$ & $5.1 \pm 1.1$ & $16.5 \pm 0.9$ & $4.8 \pm 0.9$ \\
\hline \multicolumn{2}{|c|}{ Incubation mixture } & \multicolumn{4}{|c|}{ CSF exo-enzymes activity $\left(\mathrm{nmol} \times \mathrm{min}^{-1} \times \mathrm{mg}^{-1}\right)^{*}$} \\
\hline \multirow[t]{2}{*}{ Ion } & Inhibitor & $\mathrm{ATP}=>\mathrm{ADP}$ & $\mathrm{ATP}=>\mathrm{AMP}$ & $A D P=>A M P$ & $\mathrm{ADP}=>\mathrm{ATP}$ \\
\hline & & $\mathrm{pH} 7.0$ & $\mathrm{pH} 8.0$ & $\mathrm{pH} 7.5$ & $\mathrm{pH} 6.5$ \\
\hline \multirow[t]{3}{*}{$\mathrm{Ca}^{2+}$} & Control (without inhibitor) & $21.1 \pm 2.6$ & $4.0 \pm 0.8$ & $18.1 \pm 2.1$ & $18.5 \pm 2.1$ \\
\hline & Suramine & $10.9 \pm 0.9$ & $2.7 \pm 0.9$ & $11.2 \pm 1.1$ & $17.6 \pm 1.2$ \\
\hline & Ap5A & $11.9 \pm 1.2$ & $2.8 \pm 1.2$ & $14.9 \pm 0.8$ & $4.6 \pm 0.7$ \\
\hline \multirow[t]{3}{*}{$\mathrm{Mg}^{2+}$} & Control (without inhibitor) & $23.0 \pm 3.5$ & $5.9 \pm 2.3$ & $25 \pm 1.9$ & $24.5 \pm 2.1$ \\
\hline & Suramine & $13.2 \pm 2.3$ & $3.8 \pm 1.6$ & $15.2 \pm 2.3$ & $23.5 \pm 3.2$ \\
\hline & Ap5A & $11.2 \pm 1.6$ & $4.4 \pm 1.6$ & $9.1 \pm 0.1$ & $5.3 \pm 0.8$ \\
\hline
\end{tabular}




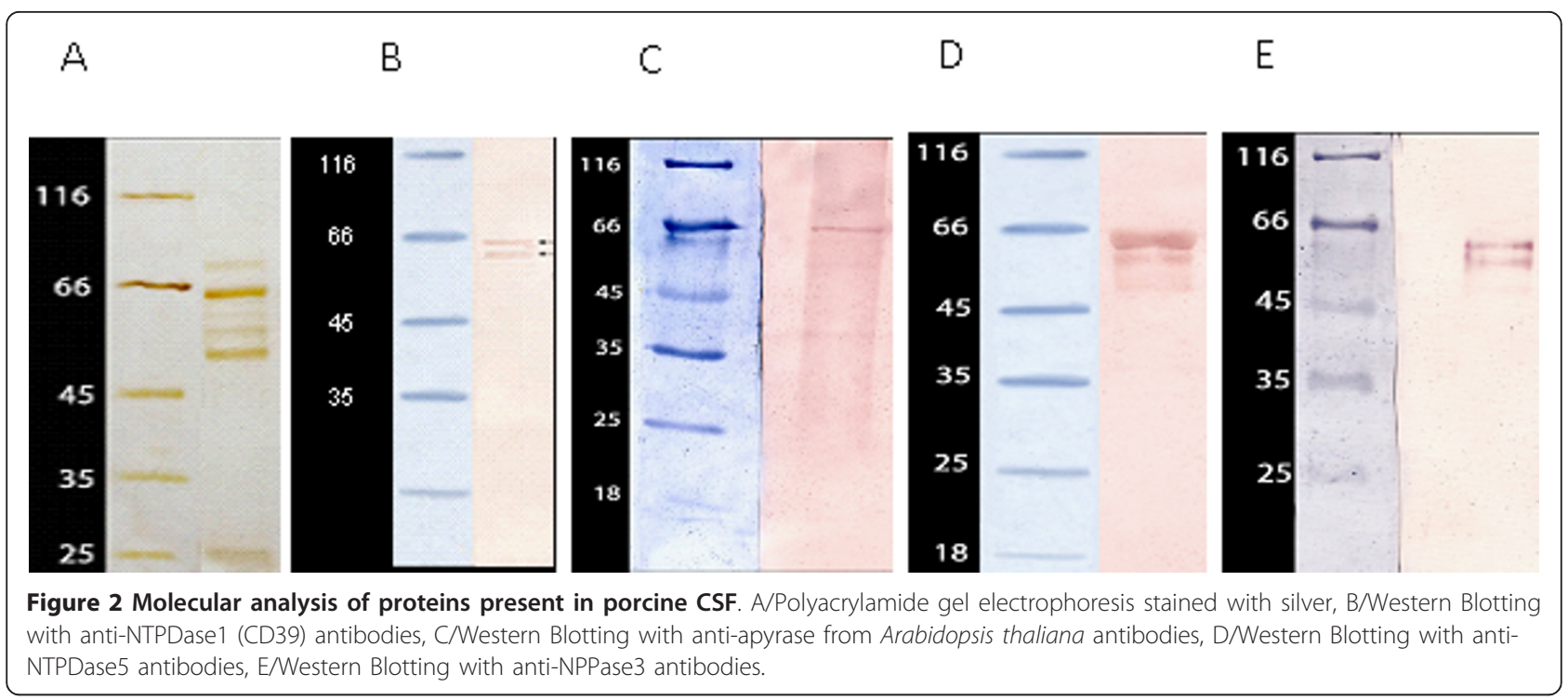

Nucleotides and nucleosides of porcine brain ventricular system

The presence of ATP, ADP and other tri- and diphosphonucleotides in human CSF was indicated for the first time by Czarnecka et al. [32]. The rabbit CSF also possesses a wide range of various compounds including adenosine, guanosine, uridine, cytidine, inosine, tymidine, deoxycytidine, deoxyuridine, hipoxanthine, xanthine and uric acid. The concentration of these compounds was tested in normal physiological conditions, during starving and liver damage [60,61]. Similarly, rodents were also shown to carry nucleotides in their CSF $[60,61]$.

Our experiments indicated that similar to the concentration of purines in human tissue fluids [1-4,12-14] median values of ATP, ADP, AMP, GTP, GDP, UTP, UDP and adenosine in swine CSF ranged from 1 to 2 $\mu \mathrm{M}$.

We further found that concentrations of guanine nucleotides in analyzed CSF are significantly (about 8 times) higher than adenine nucleotides concentrations. The high concentrations of guanine nucleotides in porcine CSF are probably due to the absence of ecto- and exo-enzymes capable of specific guanine nucleotides hydrolysis. The maintaining of high level of guanine nucleotides suggests an important role for these nucleotides in ventricular system physiology. Though the precise function of guanine nucleotides is still unclear, however. More recent studies suggest the participation of GTP and guanosine in metabotropic (P2Y) receptors

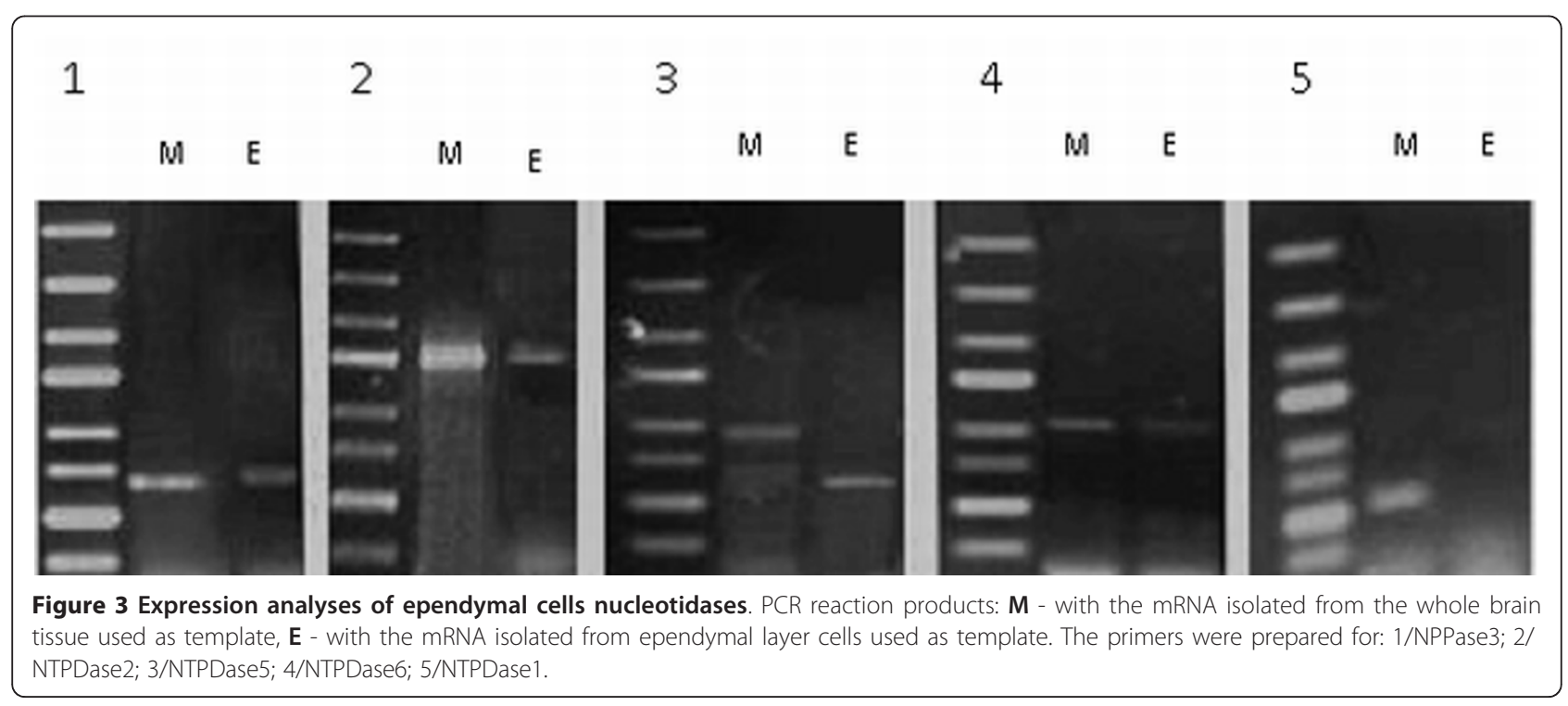


activation during regulation of ATP and adenosine exocytosis [17,18,62-66]. Additionally, the latest data indicate that guanine nuclotides can act as trophic agents [18].

The correlation between concentration of nucleotides, nucleosides and purine/pyrimidine bases in extracellular spaces of brain tissue on one hand and in cerebrospinal fluid on the other, suggests that changes in CSF composition may reflect changes in the brain condition $[1-4,12-14]$. Numerous authors claim that brain hypoxia results in ATP degradation and in signifficant increase of degradation products in CNS cells. Some of the products, like adenosine, can be released in cerebrospinal fluid [17,18,67-69]. On the other hand, the changes in the CNS cells metabolism can induce intensified exocytosis of ATP and ADP $[19,68]$. Damaged brain cells constitute another source of purines and pyrimidines [19].

\section{Nucleotide receptors}

The nucleotide receptors were found in all organs and tissues examined so far [19]. In rodents ventricular system their existence was confirmed immunochemically $[15,16]$. The PCR method allowed to detect mRNA of nucleotide receptors in cells of choroid plexus and spinal cord neurons that come in contact with CSF in rodents $[15,70]$. However, these studies did not successfully determine the exact amount and localization of these receptors on the cell surface. The results presented in this paper indicate that nucleotide receptors $\mathrm{P}_{2} \mathrm{X}_{2}, \mathrm{P} 2 \mathrm{X}_{7}$ and $\mathrm{P} 2 \mathrm{Y}_{2}$ are expressed on the ependymocytes of lateral ventricle of porcine brain. Their amount and distribution has been found to be diverse. The $\mathrm{P}_{2} \mathrm{X}_{7}$ receptors connected with inflammatory reactions and pain [71] were predominantly expressed on the analysed tissue fragments. The density of $\mathrm{P}_{2} \mathrm{X}_{2}$ i $\mathrm{P} 2 \mathrm{Y}_{2}$ receptors was low, whereas P2Y receptors were distributed irregularly in form of streaks and $\mathrm{P} 2 \mathrm{X}$ receptors were scattered on the ependymocytes surface. The presence of nucleotide receptors in the areas contacting with CSF suggests the possibility of communication between ependymal cells and cerebrospinal fluid via nucleotides. Furthermore, high density of $\mathrm{P}_{2} \mathrm{X}_{7}$ receptors indicates that ventricular system plays a key role in inflammatory processes in central nervous system since in recent years, the role of ATP and $\mathrm{P}_{2} \mathrm{X}_{7}$ receptors in these processes has been recognised [72-74]. It was also found that injury inflicted on rat brain by heme injection resulted in increased interleukine concentration in CSF [75]. We detected the elevated concentration of ATP in CSF of patients with brain stroke (unpublished data). The results discussed above confirm the thesis about cross-talking between brain and ventricular system functioning in physiological as well as pathological conditions.
Nucleotide receptors, like all the receptors of neurotransmitters in the ventricular system, may also be involved in the regulation of cilliae movement [5-11], important for CSF circulation.

\section{The enzymes acting in nucleotides metabolism of porcine brain ventricular system}

The enzymes associated with ependyma and CSF hydrolysed adenosine tri- and diphosphonucleotides effectively while guanine nucleotides were not hydrolysed as efficiently and pyrimidynes were not metabolised at all. Similar substrate specificity was found for soluble nucleotidases in rat CSF [25]. The nucleotidases in ventricular system, like the majority of so far characterised NTPDases [EC 3.6.1.5] and NPPases [EC 3.6.1.9], acted optimally in alkaline conditions at pH 7.5-8.0 $[25,29,42-49]$. These enzymes were activated by divalent ions, preferably by $\mathrm{Ca}^{2+}$ and $\mathrm{Mg}^{2+}$. Moreover, the susceptibility to inhibitors of ecto-nucleotidases and kinases (suramine and Ap5A) and alkaline phosphatases (levamisole) indicates that ecto-NTPDases as well as NPPases are active on the ependymocytes. We also realize the presence of nucleotide kinases in porcine CSF and on the surface of porcine brain ventricle lining. Inconsiderable influence of levamisole on nucleotides hydrolysis (data not shown) excludes the presence of membranous alkaline phosphatases. In summary, ectoand exonucleotidases from NTPDase and NPPase family as well as adenylate kinase participate in nucleotides metabolism in ventricular system of porcine brain.

The adenylate kinase (AK), ectoNTPDase2, NPPase and 5'-nucleotidase activities were demonstrated on the surface of ependymal cells (Figure 4). Kinetical analyses failed to verify activity of NTPDase1 and/or 3. The PCR method also confirmed the absence of NTPDase1 in ventricular system of swine. Unexpectedly, in Western Blotting anti-NTPDase1 antibodies reacted with protein of molecular mass characteristic for soluble NTPDases, which allowed us to conclude that they reacted non-specifically with NTPDase5 protein.

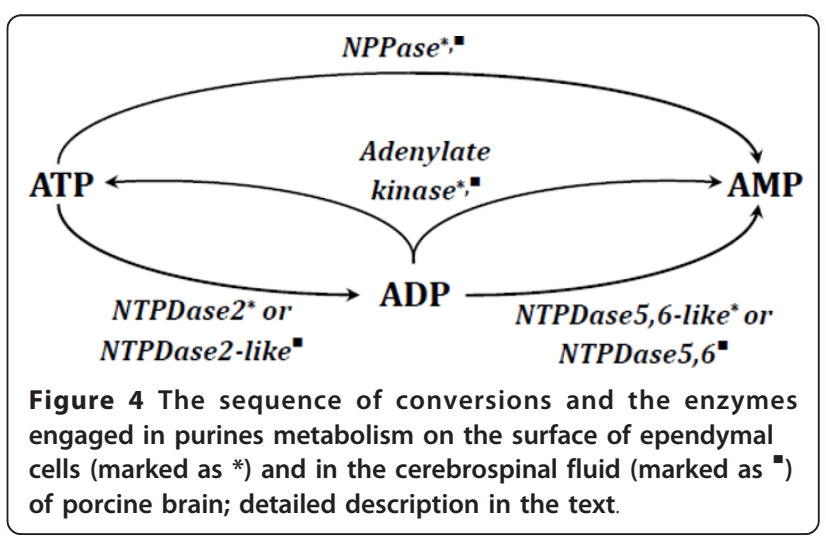


In porcine CSF we also detected the activity of NPPase and nucleotidases similar to NTPDase 2 and NTPDase 5 or 6 (Figure 4). NPPase of CSF is inhibited by Ap5A. The enzyme with similar properties was found in rat CSF [76]. Western blot analysis indicated that the proteins interacting with anti-NPPases antibodies have molecular weight of about $52 \mathrm{kDa}$ and $58 \mathrm{kDa}$. These data are in accordance with molecular weight of soluble NPPases given in literature [41-48]. One of these proteins is NPPase3, analogous to ectoNTPDases in blood vessels [76], the difference in the molecular weight (about $6 \mathrm{kDa}$ ) suggests that the second protein can be NPPase3 that might have been detached from the membrane and released to CSF.

We also detected the soluble form of NTPDase hydrolysing ATP and less efficiently ADP, which is inhibited by suramine and not by Ap5A. However, the soluble NTPDases described so far had rather high specificity to diphosphonucleosides and low specificity to triphosphonucleosides $[40,77,78]$. We also found the adenylate kinase activity in cerebrospinal fluid of swine. We detected low 5'-nucleotidase and adenosine deaminase activities in porcine CSF.

Mainly neuronal NTPDases are involved in release of the agonists from nucleotide receptors $[25,29,50]$. The end product of extracellular ATP and ADP metabolism in ventricular system is always AMP. Blood vessel NTPDase1, 2 and 3 activity and neuronal ectoNTPDases also produced AMP $[25,29,50]$. In opposition to that, we did not find NTPDase 1 and 2 in ventricular system. The product of the above reactions - extracellular AMP is further hydrolysed by ependymal 5'-nucleotidase to adenosine that is known for its neuroprotective functions $[67,69]$. The activity of 5 '-nucleotidase was found both on ependymal surface and CSF, however in CSF the hydrolysis of AMP is due to unspecific phosphatase activity.

The results of previous studies suggested that NTPDases participate in CSF nucleotides metabolism $[25,50]$. Nucleotidase activity using di- and triphosphonucleosides was detected in rat CSF, however the precise identification of these NTPDases was imposible [76]. There is little information about participation of other enzymes, for example exo-nucleotidases, in nucleotide metabolism. Previous experiments indicated the presence of NPPase 2 and 3 on chondroid plexus cells [79].

Extracellular nucleotides including ATP, ADP, UTP and UDP are signaling molecules involved in the regulation of metabolic processes throughout the nervous system $[26,27]$. In recent years the particular attention has been paid to the role of ATP and adenosine in inflammatory reactions. ATP is considered to be specific "danger signal". Released to the extracellular space ATP informs about pathological conditions and damage of cells and activates immunological response [80]. The presented results not only confirmed the presence of all elements of purinergic signaling in the mammalian brain ventricular system, but also demonstrated numerous $\mathrm{P}_{2} \mathrm{X}_{7}$ receptors expressed on the surface of ependymal cells. These observations suggest that the ventricular system is responsible for initiating the inflammation reactions triggered off by the damage of brain cells. Relevance of these observations is elevated due to the fact that increased concentration of ATP, ADP and GTP in CSF of patients with brain stroke may be connected with higher death risk (unpublished data).

\section{Acknowledgements}

This research was supported by project "Step into the Future" granted by Marshal of The Kuyavian-Pomeranian Voivodeship.

\section{Author details}

${ }^{1}$ Biochemistry Department, Institute of General and Molecular Biology, Nicolaus Copernicus University, 7 Gagarina St, 87-100 Torun, Poland. ${ }^{2}$ Department of Swine Diseases, National Veterinary Research Institute, 57 Partyzantow Avenue, 24-100 Pulawy, Poland. ${ }^{3}$ Cell Biology Department, Institute of General and Molecular Biology, Nicolaus Copernicus University, 7 Gagarina St, 87-100 Torun, Poland.

\section{Authors' contributions}

JC carried out the biochemical analyses and molecular studies and drafted the manuscript, KR participated in the biochemical analyses and drafted the manuscript, AJ have been involved in the collection and preparation of animal material, DS carried out the immunochemical experiments, MK contributed conception and design of the study, analysis and interpretation of the data and drafting the manuscript. All authors read and approved the final manuscript.

\section{Declaration of competing interests}

The authors declare that they have no competing interests.

Received: 18 March 2011 Accepted: 13 October 2011

Published: 13 October 2011

\section{References}

1. Rodrigues-Nunez A, Camina F, Lojo S, Rodrigues-Segade S, Castro-Gago M: Concentration of nucleotides, nucleosides, purine bases and urate in cerebrospinal fluid of children with meningitis. Acta Peadiatr 1993, 82:849-52.

2. Schmidt H, Siems WG, Grune T, Grauel EL: Concentration of purine compounds in the cerebrospinal fluid of infants suffering from sepsis, convulsion and hydrocephalus. J Perinat Med 1995, 23:167-174.

3. Holst H, Sollevi A: Increased concentration of hypoxanthine in human central cerebrospinal fluid after subarachnoid haemorrhage. Acta Neurochir 1983, 77:52-59.

4. Stover JF, Lowitzsch K, Kempski OS: Cerebrospinal fluid hypoxanthine, xanthine and uric acidlevels may reflect glutamate - mediated exitotoxicity in different neurological diseases. Neurosci Lett 1997, 238:25-28.

5. Tang FR, Sim MK: Metabotropic glutamate receptor subtype alfa (mGluR1alfa) immunoreactivity in ependymal cells of rat caudal medulla oblongata and spinal cord. Neurosci Lett 1997, 225:177-180.

6. Yanase $\mathrm{H}$, Shimizu H, Yamada K, Iwanaga T: Cellular Localization of the Diazepam Binding Inhibitor in Glial Cells with Special Reference to Its Coexistence with Brain-type Fatty Acid Binding Protein. Arch Histol Cytol 2002, 65:27-36

7. Rating D, Siemes $H$, Löscher W: Low CSF GABA concentration in children with febrile convulsions, untreated epilepsy, and meningitis. J Neurol 1983, 230:217-25. 
8. Weiner M, Speciale S, Risser R, Kramer G, Petty F: Cerebrospinal fluid and plasma gamma-aminobutyric acid in Alzheimer's disease. Biol Psychiatry 1996, 40:933-934.

9. Jiménez-Jiménez FJ, Molina JA, Gómez P, Vargas C, de Bustos F, Benito J, Tallón-Barranco A, Ortí-Pareja M, Gasalla T, Arenas J: Neurotransmitter amino acids in cerebrospinal fluid of patients with Alzheimer's disease. $J$ Neural Transm 1998, 105:269-277.

10. Tomé M, Moreira E, Pérez-Fígares JM, Jiménez AJ: Presence of D1- and D2like dopamine receptors in the rat, mouse and bovine multiciliated ependyma. J Neural Transm 2007, 114:983-994.

11. Rodríguez S, Vio K, Wagner C, Barría M, Navarrete EH, Ramírez VD, PérezFígares JM, Rodríguez EM: Changes in the cerebrospinal-fluid monoamines in rats with an immunoneutralization of the subcommissural organ-Reissner's fiber complex by maternal delivery of antibodies. Exp Brain Res 1998, 128:278-290.

12. Rodriguez-Nunez A: Neuron-specific enolase, nucleotides, nucleosides, purine bases, oxypurines and urid amid concentration in cerebrospinal fluid of children with meningitis. Brain Dev 2003, 25:102-106.

13. Rodríguez-Núnez A, Camiña F, Lojo S, Rodríguez-Segade S, Castro-Gago M: Purine metabolites and pyrimidine bases in cerebrospinal fluid of children with simple febrile seizures. Dev Med Child Neurol 1991, 33:908-11.

14. Castro-Gago M, Camiña F, Lojo S, Rodríguez-Segade S, Rodríguez-Núñez A: Concentrations of purine nucleotides and purine and pyrimidine bases in cerebrospinal fluid of neurologically healthy children. Eur J Clin Chem Clin Biochem 1992, 30:761-5.

15. Stoeckel ME, Uhl-Bronner $\mathrm{S}$, Hugel $\mathrm{S}$, Veinante $\mathrm{P}$, Klein MJ, FreundMercier MJ, Schlichter R: Cerebrospinal fluid cocntacting neurons in the rat spinal cord, a $\gamma$-aminobutiric acidergic system expressing the P2X2 subunit of purynergic receptors, PSA-NCAM, and GAP-43 immunoreactivities: light and electron microscopic study. I Comp Neurol 2003, 457:159-174

16. Collo G, Neidhart S, Kawashima E, Kosco-Villbois M, North RA, Buell G: Tissue Distribution of the P2X7 Receptor. Neuropharm 1997, 36:1277-1283.

17. Rathbone M, Middlemiss P, Gysbers J, Andrew C, Herman M, Reed J, Ciccarelli R, lorio P, Caciagli F: Trophic effect of purines in neurons and glial cells. Prog Neurobiol 1999, 59:663-690.

18. Ciccarelli R, Ballerini P, Sabatino G, Rathbone MP, D'Onofrio M, Caciagli F, Iorio P: Involement of astrocytes in purine mediated reparative processes in the brain. Int I Devl Neurosci 2001, 19:359-414.

19. Ralevic $V$, Burnstock $G$ : Receptors for purines and pyrimidines. Am J Pharmacol Exp Ther 1998, 50:413-492.

20. Jacobson KA, Hoffmann C, Cattabeni F, Abbracchio MP: Adenosineinduced cell death: evidence for receptor-mediated signaling. Apoptosis 1999, 4:197-211.

21. Schubert P, Ogata T, Marchini C, Ferroni S, Rudolphi K: Protective mechanisms of adenosine in neurons and glial cells. Ann N Y Acad Sci 1999, 825:1-10.

22. Burnstock G: Development and perspectives of the purinoceptors concept. J Auton Pharmacol 1996, 16:295-302.

23. Burnstock $G$, Knight $G E$ : Cellular distribution and functions of $P 2$ receptor subtypes in different systems. Int Rev Cytol 2004, 240:301-304.

24. Harden TK, Lazarowski ER, Boucher RC: Release, metabolism and interconversion of adenine and uridine nucleotides: Implications for $\mathrm{G}$ protein-coupled P2 receptor agonist selectivity. Trends Pharmacol Sci 1997, 18:43-46.

25. Zimmermann H: Extracellular purine metabolism. Drug Dev Res 1996, 39:337-352.

26. Zimmermann H: Signalling via ATP in the nervous system. Trends Neurosci 1994, 17:420-425.

27. Burnstock G: Purinergic signalling: past, present and future. Braz J Med Biol Res 2009, 42:3-8.

28. Koziak K: CD39 (NTPDase 1) - Characteristics of the enzyme and its role in regulating coagulation and inflammation processes. Post Biol Kom 2002, 29:15-25.

29. Zimmermann H, Braun N, Heine P, Kohring K, Marxen M, Sévigny J, Robson SC: The molecular and functional properties of E-NTPDase1, ENTPDase2 and ecto-5'-nucleotidase in nervous tissue. In Ecto-ATPases and related ectonucleotidases. Edited by: VanDuffel L, Lemmens R. Maastricht: Shaker Publishing BV; 2000:9-20.
30. Xiang Z, Burnstock G: Expression of P2X receptors in rat choroid plexus. Neuroreport 2005, 16:903-907.

31. Oses J, Viola G, de Paula Cognato G, Júnior V, Hansel G, Böhmer A, Leke R, Bruno A, Bonan C, Bogo M, Portela L, Souza D, Sarkis J: Pentylenetetrazol kindling alters adenine and guanine nucleotide catabolism in rat hippocampal slices and cerebrospinal fluid. Epilepsy Res 2007, 75:104-111.

32. Czarnecka J, Cieślak M, Komoszyński M: Application of solid phase extraction and high-performance liquid chromatography to qualitative and quantitative analysis of nucleotides and nucleosides in human cerebrospinal fluid. J Chromatogr B Analyt Technol Biomed Life Sci 2005, 822:85-90.

33. Van Belle H: Alkaline phosphatase. Kinetics and inhibition by levamisole of purified isoenzymes from humans. Clin Chem 1976, 22:972-976.

34. Wu PH, Phillis JW: Uptake of Adenosine by Isolated Rat Brain Capillaries. J Neurochem 1982, 38:687-690.

35. Kukulski F, Komoszyński M: Purification and characterization of NTPDase1 (ecto-apyrase) and NTPDase2 (ecto-ATPase) from porcine brain cortex synaptosomes. Eur J Biochem 2004, 270:3447-3454.

36. Cauwenberghs S, Feijge M, Hageman G, Hoylaerts M, Akkerman JW, Curvers J, Heemskerk J: Plasma ectonucleotidases prevent desensitization of purinergic receptors in stored platelets: importance for platelet activity during thrombus formation. Transfusion 2006, 46:1018-1028.

37. Kurebayashi N, Kodama T, Ogawa Y: P1, P5-Di(Adenosine-5') Pentaphosphate(Ap5A) as an Inhibitor of Adenylate Kinase in Studies of Fragmented Sarcoplasmic Reticulum from Bullfrog Skeletal Muscle. J Biochem 1980, 88:871-876.

38. Bradford MM: A rapid and sensitive method for the quantification of microgram quantities of protein utilizing the principle of protein dye binding. Anal Biochem 1976, 72:248-254.

39. Sato K, Kubota T, Ishida M, Yoshida K, Takeuchi H, Handa Y: Immunohistochemical and ultrastructural study of chordoid glioma of the third ventricle: its tanycytic differentiation. Acta Neuropathol 2003, 106:176-180.

40. Osesa JP, Cardosoa CM, Albuquerque GR, Barreto Kl, Rucker B, Ribas FC, Wink MR, Bonan CD, Battastini AMO, Freitas Sarkis JJ: Soluble NTPDase: An additional system of nucleotide hydrolysis in rat blood serum. Life Sci 2004, 74:3275-3284.

41. Sakagami H, Aoki J, Natori $Y$, Nishikawa K, Kakehi $Y$, Natori $Y$, Arai H: Biochemical and Molecular Characterization of a Novel Choline-specific Glycerophosphodiester Phosphodiesterase Belonging to the Nucleotide Pyrophosphatase/Phosphodiesterase (NPP) family. J Biol Chem 2005, 23:1-30.

42. Zimmermann H: Extracellular metabolism of ATP and other nucleotides. Naunyn-Schmiedeberg's Arch Pharmacol 2000, 362:299-309.

43. Novak I: ATP as a Signaling Molecule: the Exocrine Focus. News Physiol Sci 2003, 18:12-17.

44. Finger TE, Danilova V, Barrows J: ATP signaling is crucial for communication from taste buds to gustatory nerves. Science 2005, 310:1495-1499.

45. Lazarowski ER, Boucher RC, Kendall HT: Mechanisms of Release of Nucleotides and Integration of Their Action as P2X- and P2Y-Receptor Activating Molecules. Mol Pharmacol 2003, 64:785-795.

46. Godinga JW, Grobbenb B, Slegers H: Physiological and pathophysiological functions of the ecto-nucleotide pyrophosphatase/phosphodiesterase family. Biochim Biophys Acta 2003, 1638:1-19.

47. Bollen M, Gijsbers R, Ceulemans H, Stalmans W, Stefan C: Nucleotide pyrophosphatase/phosphodiesterase on the move. Crit Rev Biochem Mol Biol 2000, 35:393-432.

48. Yano Y, Hayashi Y, Sano K, Shinmaru H, Kuroda Y, Yokozaki HI, Yoon S, Kasuga M: Expression and localization of ecto-nucleotide pyrophosphatase/phosphodiesterase I-3 (E-NPP3/CD203C/PD-IB/B10/ gp130RB13-6) in human colon carcinoma. Int J Mol Med 2003, 12:763-766.

49. Fausther M, Lecka J, Kukulski F, Lévesque SA, Pelletier J, Zimmermann $H_{\text {, }}$ Dranoff JA, Sévigny J: Cloning, purification and identification of the liver canalicular ecto-ATPase as NTPDase8. Am J Physiol Gastrointest Liver Physiol 2006, 9:785-795

50. Simon C, Robson SC, Sévigny J, Zimmermann H: The E-NTPDase family of ectonucleotidases: Structure function relationships and pathophysiological significance. Purinergic Signal 2006, 2:409-430

51. Silva-Alvarez C, Carraro M, Balmaceda-Aguilera C, Pastor P, Angeles GM, Reinicke K, Aguayo L, Molina B, Cifuentes M, Medina R, Nualart F: 
Ependymal cell differentiation and GLUT1 expression is synchronous process in the ventricular wall. Neurochem Res 2005, 30:1227-1236.

52. Oshio K, Binder D, Yang B, Schecter S, Verkman A, Manley G: Expression of aquaporin water channels in mouse spinal cord. Neuroscience 2004, 127:685-693.

53. Steiniger $B$, van der Meide PH: Rat ependyma and microglia cells express class II MHC antigens after intravenous infusion of recombinant gamma interferon. J Neuroimmunol 1988, 19:111-118.

54. Hauwel M, Furon E, Canova C, Griffiths M, Neal J, Philippe P: Innate (inherent) control of brain infection, brain inflammation and brain repair: the role of microglia, astrocytes, "protective" glial stem cells and stromal ependymal cells. Brain Res Rev 2005, 48:220-233.

55. Li Y, Chen J, Chopp M: Cell proliferation from ependymal, subependymal and choroid plexus cell in response to stoke in rats. J Neurol Sci 2002, 193:137-146.

56. Verleysdonka S, Kistnera S, Pfeiffer-Guglielmia B, Wellarda J, Lupescub A, Laskec J, Langb F, Rappd M, Hamprechta B: Glycogen metabolism in rat ependymal primary cultures: Regulation by serotonin. Brain Res 2005, 1060:89-99.

57. Gotts J, Chesselet M: Mechanisms of subventricular zone expansion after focal cortical ischemic injury. J Comp Neurol 2005, 25:201-214.

58. Ong J, Plane J, Parent J, Silverstein F: Hypoxic-ischemic injury stimulates subventricular zone proliferation and neurogenesis in the neonatal rat. Pediatr Res 2005, 58:600-606.

59. Quinones-Hinojosa A, Sanai N, Soriano-Navarro M, Gonzalez-Perez O, Mirzadech Z, Gil-Perotin S, Romero-Rodriguez R, Berger M, GarciaVerdugo JM, Alvarez-Buylla A: Cellular composition and cytoarchitecture of the adult human Subventricular Zone: a niche of neural stem cells. J Comp Neurol 2006, 494:415-434.

60. Eells J, Spector R: Determination of ribonucleosides, deoxyribonucleosides, and purine and pyrimidine bases in adult rabbit cerebrospinal fluid and plasma. Neurochem Res 1983, 8:1307-1320.

61. Eells J, Spector R, Huntoon S: Nucleoside and oxypurine homeostasis in adult rabbit cerebrospinal fluid and plasma. J Neurochem 1984, 42:1620-1624.

62. Soares F, Schmidt A, Farina M, Frizzo M, Tavares R, Portela L, Lara D, Souza D: Anticonvulsant effect of GMP depends on its conversion to guanosine. Brain Res 2004, 1005:182-186.

63. Deutsch S, Long K, Rosse R, Mastropaolo J, Eller J: Hypothesized deficiency of guanine-based purines may contribute to abnormalities of neurodevelopment, neuromodulation, and neurotransmission in LeschNyhan syndrome. Clin Neuropharmacol 2005, 28:28-37.

64. Frizzo M, Antunes Soares F, Dall'Onder L, Lara D, Swanson R, Souza D: Extracellular conversion of guanine-based purines to guanosine specifically enhances astrocyte glutamate uptake. Brain Res 2003, 972:84-89

65. Schmidt A, Lara D, de Faria Maraschin J, da Silveira Perla A, Onofre Souza D: Guanosine and GMP prevent seizures induced by quinolinic acid in mice. Brain Res 2000, 864:40-43

66. Schmidt A, Böhmer A, Leke R, Schallenberger C, Antunes C, Pereira M, Wofchuk S, Elisabetsky E, Souza D: Antinociceptive effects of intracerebroventricular administration of guanine-based purines in mice: evidences for the mechanism of action. Brain Res 2008, 1234:50-58.

67. Latini S, Pedata F: Adenosine in the central nervous system: release mechanisms and extracellular concentrations. J Neurochem 2001, 79:463-484.

68. Moatassim C, Dornand J, Mani J: Extracellular ATP and cell signaling. Biochim Biophys Acta 1992, 1134:31-45.

69. Wardas J: Neuroprotective role of adenosine in CNS. Pol J Pharmaco 2002, 54:313-326.

70. Gever J, Cockayne D, Dillon M, Burnstock G, Ford A: Pharmacology of P2X channels. Pflugers Arch 2006, 452:513-537.

71. Di Virgilio F: P2 Receptors of microglia: sensors for danger signals in the CNS. J Neurochem 2002, 81:115.

72. Dell'Antonio G, Quattrini A, Dal Cin E, Fulgenzi A, Ferrero $M$ : Antinociceptive effect of a new P2Z/P2X7 antagonist, oxidized ATP, in arthritic rats. Neurosci Lett 2002, 327:87-90.

73. Ballerini P, Ciccarelli R, Caciagli F, Rathbone M, Werstiuk E, Traversa U, Buccella S, Giuliani P, Jang S, Nargi E, Visini D, Santavenere C, Di lorio P: $\mathrm{P} 2 \mathrm{X7}$ receptor activation in rat brain cultured astrocytes increases the biosynthetic release of cysteinyl leukotrienes. Int I Immunopathol Pharmacol 2005, 18:417-430.

74. Gandelman M, Peluffo H, Beckman J, Cassina P, Barbeito L: Extracellular ATP and the P2X7 receptor in astrocyte-mediated motor neuron death implications for amyotrophic lateral sclerosis. J Neuroinflammation 2010, 7:33.

75. Walentynowicz K, Szefer M, Wojtal B, Terlecki P, Wrotek S, Kozak W: Role of prostaglandins in heme-induced fever. J Physiol Pharm 2006, 57:73-82.

76. Cruz Portela L, Oses J, Silvera A, Schmidt A, Lara D, Oliveira Bastini A, Ramirez G, Vinade L, Freitas Sarkis J, Souza D: Guanine and adenine nucleotidaseactivities in rat cerebrospinal fluid. Brain Res 2002, 1:74-78

77. Todorov L, Mihaylova-Todorova S, Westfall T, Sneddon P, Kennedy C, Bjur R, Westfall D: Neuronal release of soluble nucleotidases and their role in neurotransmitter inactivation. Nature 1997, 387:76-79.

78. Yang M, Kirley TL: Engineered human soluble calcium-activated nucleotidase inhibits coagulation in vitro and thrombosis in vivo. Thromb Res 2008, 122:541-548.

79. Stefan C, Jansen S, Bollen M: Modulation of purinergic signaling by NPPtype ectophosphodiesterases. Purinergic Signal 2006, 2:361-370.

80. Trautmann A: Extracellular ATP in immune system: more than just a danger signal. Sci Signal 2009, 2:1-3.

doi:10.1186/1751-0147-53-54

Cite this article as: Czarnecka et al: Some aspects of purinergic signaling in the ventricular system of porcine brain. Acta Veterinaria Scandinavica 2011 53:54.

\section{Submit your next manuscript to BioMed Central and take full advantage of:}

- Convenient online submission

- Thorough peer review

- No space constraints or color figure charges

- Immediate publication on acceptance

- Inclusion in PubMed, CAS, Scopus and Google Scholar

- Research which is freely available for redistribution

Submit your manuscript at www.biomedcentral.com/submit
Ciomed Central 